\title{
Perceived risk and its role in the influence of brand awareness on purchase intention: study of Shopee users
}

\author{
Sri Rahmi ${ }^{1}$, Gunawan Bata Ilyas ${ }^{2}$, Hasmin Tamsah $^{3}$, Abdul Razak Munir ${ }^{4}$ \\ 1,2,3 STIE Amkop Makassar, Makassar, Indonesia \\ ${ }_{4}^{4}$ Universitas Hasanuddin, Makassar, Indonesia \\ *Corresponding author: srahmi1310@gmail.com
}

\begin{tabular}{l} 
Article Info \\
\hline Article history: \\
Received : 23 March 2021 \\
Accepted: 16 September 2021 \\
Published: 1 January 2022
\end{tabular}

JEL Classification Code: M31, M37, Z33

\section{Author's email: \\ fadelgun@yahoo.co.id hasmintamsah@gmail.com arazak.munir@gmail.com}

DOI: 10.20885 /jsb.vol26.iss1.art7

\begin{abstract}
Purpose: This research aimed to analyze the role of perceived risk in the relationship between brand awareness and purchase intention. This research is important because the perceived risk of online purchasing can influence consumer purchasing behavior.
\end{abstract}

Design/methodology/approach: This research used an explanatory study with a quantitative approach. The research was conducted on 112 Shopee users in Makassar City. Data were collected through an online questionnaire. The data collected were analyzed using the Structural Equation Modelling (SEM) with the AMOS application and the Sobel Test to test the indirect relationship.

Findings: Risk, financial risk, time risk, delivery risk, and privacy risk were essential elements forming perceived risk. Brand awareness had a positive influence on purchase intention. Perceived risk was a variable that mediated the influence of brand awareness on purchase intention.

Originality/value: The results of this research indicated that the more aware consumers are of a brand, the negative perceptions of the brand will appear due to the ease with which information was disseminated and accepted by consumers. Perception of risk is a factor that can reduce consumer buying interest. Consumer purchase intention towards a known brand will decrease if the brand is perceived as having a high risk.

Research limitation: This research was conducted on most students who did not yet have stable financial capabilities. For further studies, we suggest using respondents who have better financial ability to provide a more tangible measurement of purchasing ability.

Practical implication: Results showed that perceived risk could reduce the influence of brand awareness on purchase intention. Thus, minimizing risk, ensuring the absence of perceived negative things before choosing a brand, and ensuring consumer comfort in using a brand were factors encouraging purchase intention.

Keywords: brand awareness, perceived risk, purchase intention, theory of planned behavior

\section{Introduction}

Online purchasing and its influencing factors are always exciting things to discuss. Online consumption through e-commerce in Indonesia is increasing from year to year due to increasingly accessible online buying and selling sites. Consumers are increasingly accustomed to using technology in their daily activities.

Hootsuite (2020) showed that out of 272 million people in Indonesia, 175.4 million are internet users. There was an increase of 17 percent or around 25 million people since January 
2019. Of this number, 93 percent searched for products to be purchased online, 90 percent directly visited the online shops, and 88 percent made a purchase online.

Previous researchers confirmed that online purchasing has a higher risk than direct purchases (Hashemi \& Hajiheydari, 2012; Silaban et al., 2020; Yang \& Zhang, 2009). The higher the perceived risk, the lower the interest in consuming a brand (Chen, 2013; Wang \& Hazen, 2015). However, based on the Hootsuite data, there was a significant increase in online visitors and buyers in Indonesia. This shows that the high risk of online shopping does not affect the interest in making online purchases. Research by Kurniawan \& Indriani (2018) also stated that perceived risk has no significant effect on purchase intention. Furthermore, the research states that the perceived risk of consumers does not reduce buying interest.

Risk is defined as uncertainty on the negative consequences (Ariffin et al., 2018), including online purchases (Chen, 2013). According to Bauer \& Raymond (1960), perceived risk is the uncertainty and negative consequences of certain behavior. However, Peter \& Ryan (1976) argued that if consumers think that a brand is unacceptable from the beginning, there will be no more uncertainty and risk perception. Rubio et al. (2014) defined perceived risk as the negative event from something expected. Perceived risk is a consumer's belief in the negative uncertainty of online shopping (Wu et al., 2020). The expectation arises from the brand information. Therefore, consumers must know the brand first to predict the risk of consuming that brand.

According to Aaker \& Biel (2013), brand awareness can be recognized by consumers. This research focused on Shopee as one of the most recognized e-commerce in Indonesia. MarkPlus reported that Shopee is first and very far ahead of other e-commerce companies for brand awareness with $71 \%$, followed by Tokopedia of $15 \%$ and Lazada of $8 \%$ (Tempo.com, 2020). iPrice (2020) also showed that Shopee has the most visitors in 2020, which means most consumers choose Shopee to shop online than others. The researchers analyzed the reason of online shopping has significat increase eventhough it has high risk.

The purpose of this research is to measure the direct influence of brand awareness on perceived risk and purchase intention and the influence of perceived risk on purchase intention. Previous researches have discussed the relationship between brand awareness, perceived risk, and purchase intention. However, there are still very few researches that discuss the negative influence of consumer awareness of certain brands. In this research, the researchers also analyzed the role of product risk, financial risk, time risk, delivery, and privacy risk in measuring perceived risk and the role of perceived risk in the relationship between brand awareness and purchase intention.

\section{Literature Review and Hypothesis}

\section{Theory of Reasoned Action (TRA) and Theory of Planned Behavior (TPB)}

Predicting consumer behavior in purchasing is one of the main functions of marketing. By making the correct predictions, marketers can develop strategies to deliver products in the proper position of market competition. Based on the Theory of Reasoned Action (TRA) developed by Fishbein \& Ajzen (1975), one of the main points in predicting consumer behavior is through interest (Gracia \& De Magistris, 2007).

Interest is formed from the level of belief and perception. Consumers form beliefs and perceptions based on the information obtained. In this era, information can be obtained anywhere. In this research, we refer to the development of TRA by Ajzen (1991) to become the Theory of Planned Behavior (TPB) by adding internal and external influences as controls in behavior (Wang et al., 2012).

TPB is a capable theory used in predicting human behavior in various activities (Indiani \& Fahik, 2020). With three essential aspects, namely attitude, subjective norms, and Perceived Behavioral Control (PBC), TPB is an essential theory in analyzing marketing activities, including online consumer purchasing behavior. Likewise, this research used TPB to analyze how consumers behave, recognize a brand, and perceive the brand based on the information obtained to create an interest in making purchases. 


\section{Relationship between Brand Awareness and Perceived Risk}

As one of the main assets for many industries, branding has always received particular attention in the marketing process (Jalilvand \& Samiei, 2012). Sprout (2019) reported that increasing brand awareness is social marketing's top goal. Although it takes a relatively long time, the success of the branding process will bring a company to be more valuable in the future (Aaker \& Biel, 2013; Chi, 2009).

Shahid et al. (2017) stated that the product would develop better and will generate significant profits for the company with high brand awareness. Brand awareness is one of the brand equity fundamental dimensions (Chen \& He, 2003; Ilyas et al., 2020; Moisescu, 2009).

According to Khurram et al. (2018), brand awareness consists of two essential parts: recall and recognition. Recall is the ability of consumers to remember the brand in a specific product category. At the same time, recognition is the ability of consumers to recognize a brand when hearing or seeing information about a product. Brand awareness is also measured by consumption or the ability of consumers to remember a brand while consuming another brand. Besides consumption, brand awareness is also measured by purchase or the selection of a particular brand than several brands in the same product category (Pomalaa et al., 2018; Yunita et al., 2019)

As previously mentioned, online purchasing has a greater risk than offline purchasing (Ariffin et al., 2018). Hashemi \& Hajiheyi (2012) stated that in e-purchasing, brand awareness could affect perceived risk because it will increase online consumer trust. The higher the brand awareness, the more positive the perception will be (Yang et al., 2015).

Previous studies stated that brand awareness has a negative influence on perceived risk (Chen \& Chang, 2012; Rubio et al., 2014). However, Mitchell (1999) discussed various definitions and characteristics of perceived risk, including distinguishing the risk and uncertainty with two essential components: likelihood and consequence. Based on the results, perceived risk can be designed in various models based on the objectives.

Based on the understanding that perceived risk is a form of uncertainty in online purchases, a famous brand cannot guarantee the low perceived risk by consumers. With the popularity of a brand, consumers will look for information about the brand. The easier the information is obtained, the more the perceived risk will arise.

H1: Brand awareness has a positive and significant influence on perceived risk.

\section{Relationship Between Brand Awareness and Purchase Intention}

When people are aware of the brand, the higher the chance the brand will choose among similar products (Ilyas., et al., 2020; Moisescu, 2009; Shahid et al., 2017). Dabbous \& Barakat (2020) stated that a well-known brand could win the competition to become the choice to increase the purchase intention further.

Previous studies confirmed the influence of brand awareness on purchase intention (Ilyas et al., 2020; Novansa \& Ali, 2017; Petahiang et al., 2015; Shahid et al., 2017). However, Wu \& Ho (2014) stated that brand awareness could not directly increase purchase intention. It is further explained that consumers are not interested in buying products just because the product brand is famous. Consumers also tend to ignore brands while many products have the same benefits (Jean, 2015)

According to iPrice (2020), Shopee is the e-commerce with the highest number of visitors in 2020. In e-commerce, consumers are buyers and visitors to find the desired product (Suleman, 2018). Furthermore, it will encourage consumers to make purchasing decisions (Moisescu, 2009; Petahiang et al., 2015). Therefore, the higher the brand awareness, the higher the purchase intention.

H2: Brand Awareness has a positive and significant influence on Purchase Intention.

\section{Relationship Between Perceived Risk and Purchase Intention}

In the current era, perceived risk has become an essential concept in explaining consumer behavior (Ashoer \& Said, 2016; Marriott \& Williams, 2018) and purchase intention (Ariff et al., 2014; Forsythe \& Shi, 2003; Lăzăroiu et al., 2020). If the perceived risk is greater than the benefit received, it will negatively influence online consumers' trust and purchase intention (Courage et al., 2019; Forsythe \& Shi, 2003; Jayadi \& Ariyanti, 2019; Silaban et al., 2020). 
Risk is defined as the expectation of losses and an obstacle in purchase intention (Ventre \& Kolbe, 2020). Sharma \& Kurien (2017) defined perceived risk as an acceptable risk for uncertainty in consuming a product.

However, another research stated that consumers with deep concerns on the risk will find more in-depth information about the product and will continue to make purchases after obtaining a better explanation and understanding of the product (Chen \& He, 2003; Eggert, 2006; Jean, 2015; Petahiang et al., 2015)

H3: Perceived Risk has a positive and significant influence on purchase intention.

Based on previous studies, perceived risk is measured by several dimensions such as financial risk, performance risk, product risk, time risk, social risk, and other dimensions (Chen, 2013; Courage et al., 2019; Forsythe \& Shi, 2003; Ariffin et al., 2018; Tham et al., 2019; Wang, 2019). By adopting these researches, this research used financial, product, time, delivery, and privacy risks to measure perceived risk in online purchase at Shopee.

Financial risk is the possibility of consumers getting losses from purchases because of high prices, or consumers do not get the product purchased even though they have made payments. Product risk is the possibility of consumers getting undesirable product performance. Time risk is the possibility of consumers losing time from the transaction process until receiving the products purchased. Delivery risk is the possibility of consumers getting lost or damaged products during the delivery process. Finally, privacy risk is the possibility of accessing and misusing data by irresponsible parties.

In several studies, the dimensions of perceived risk influenced online purchasing behavior. Tham et al. (2019) stated that financial risk and delivery risk have a negative influence. During product and time, risk positively affects consumer behavior. Courage et al. (2019) showed that financial and product risk has a negative influence on consumer behavior. Bian \& Forsythe (2012) stated that privacy risk has a negative influence on purchase intention but has an insignificant effect on shopping behavior. Thus, this research analyzed the role of each dimension in its relationship with perceived risk to the primary variable.

H3a: Financial Risk is related to and can measure perceived risk.

H3b: Product risk is related to and can measure perceived risk.

H3c: Delivery risk is related to and can measure perceived risk.

H3d: Time risk is related to and can measure perceived risk.

H3e: Privacy risk is related to and can measure perceived risk.

Based on the above researches, brand awareness can also influence purchase intention through perceived risk. The more the brand information is obtained, the higher the perceived risk in encouraging purchase intention.

$\mathrm{H} 4=$ Brand awareness has a positive influence on purchase intention through perceived risk.

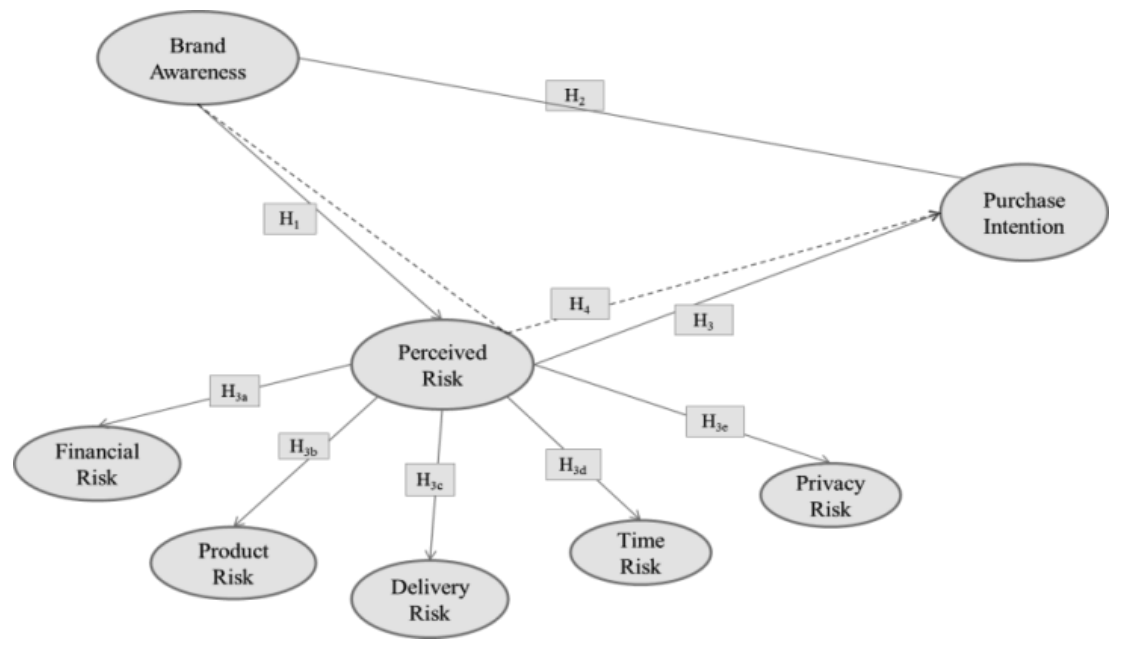

Figure I. Conceptual Framework 


\section{Research Methods}

Data were collected through an online questionnaire to Shopee users in Makassar City. The data was then analyzed using Structural Equation Modeling (SEM)- Amos with a minimum sample requirement of 100 respondents (Hair et al., 2014). Each statement item of the indicator has a specific weight based on a Likert scale, namely 1 for "strongly disagree"; 2 for "disagree"; 3 for "in doubt"; 4 for "agree," and 5 for "strongly agree.

Table 1. Variable Measurement

\begin{tabular}{lll}
\hline \multicolumn{1}{c}{ Variable } & \multicolumn{1}{c}{ Item/Indicator } & \multicolumn{1}{c}{ Major Reference } \\
\hline Brand Awareness & Recognition (RCN) & (Aaker \& Biel, 2013; Khurram et \\
& Recall (RCL) & al., 2018; Pomalaa et al., 2018; \\
& Purchase (PRC) & Yunita et al., 2019) \\
Perceived Risk & Consumption (CSM) & \\
& Financial Risk (FR) & (Chen \& Chang, 2012; Courage \\
& Product Risk (PR) & et al., 2019; Ariffin et al., 2018; \\
& Privacy Risk (PVR) & Tham et al., 2019) \\
& Delivery Risk (DR) & \\
& Time Risk (TR) & \\
Purchase Intention & Transactional Interest (TI) & (Ilyas et al., 2020; Indahingwati \\
& Interest to Transact in The Future (ITF) & et al., 2019) \\
& Interest to Recommending (IRM) & \\
\hline
\end{tabular}

Table 2. Characteristics of Respondents

\begin{tabular}{|c|c|c|c|c|}
\hline & Characteristics & & Frequency & Percentage \\
\hline \multirow[t]{3}{*}{ Gender } & & Male & 15 & 13 \\
\hline & & Female & 97 & 87 \\
\hline & Total & & 112 & 100 \\
\hline \multirow[t]{4}{*}{ Age } & & $17-25$ & 54 & 48 \\
\hline & & $26-35$ & 49 & 44 \\
\hline & & $>35$ & 9 & 8 \\
\hline & Total & & 112 & 100 \\
\hline \multirow[t]{6}{*}{ Profession } & & Entrepreneur & 17 & 15 \\
\hline & & Employees & 55 & 49 \\
\hline & & Government Employee & 10 & 9 \\
\hline & & Housewife & 7 & 6 \\
\hline & & College Student & 23 & 21 \\
\hline & Total & & 112 & 100 \\
\hline \multirow[t]{6}{*}{ Education } & & Senior High School & 31 & 28 \\
\hline & & Diploma & 17 & 15 \\
\hline & & Bachelor & 58 & 52 \\
\hline & & Master & 4 & 4 \\
\hline & & Doctor & 2 & 2 \\
\hline & Total & & 112 & 100 \\
\hline \multirow[t]{6}{*}{ Income (per month) } & & $\leq$ Rp. $1,000,000$ & 15 & 13 \\
\hline & & Rp. 1,000,001 - Rp. $2,500,000$ & 46 & 41 \\
\hline & & Rp. 2,501,000 - Rp. 5,000,000 & 41 & 37 \\
\hline & & Rp. 5,001,000 - Rp. 10,000,000 & 7 & 6 \\
\hline & & > Rp. 10,000,000 & 3 & 3 \\
\hline & Total & & 112 & 100 \\
\hline \multirow{5}{*}{$\begin{array}{l}\text { Frequency of } \\
\text { shopping at Shopee }\end{array}$} & & $\leq 3$ times / month & 62 & 55 \\
\hline & & $4-6$ times / month & 34 & 30 \\
\hline & & 7 - 10 times / month & 16 & 14 \\
\hline & & $>10$ times / month & 0 & 0 \\
\hline & Total & & 112 & 100 \\
\hline
\end{tabular}


Based on the questionnaire distributed, there were 112 Shopee users in Makassar city as the respondents. The respondents were 97 women and only 15 men. Most of them were between 17 and 25 years old (54 people), employees (55 people), undergraduate level (58 people), have an income in the range of Rp. 2,500,000 to Rp. 5,000,000 per month, and four to six purchases per month.

\section{Result and Discussion}

The data were analyzed using AMOS version 23 with two stages of measurement, namely Confirmatory Factor Analysis (CFA) and Goodness-of-Fit or model fit testing (Byrne, 2016). CFA aims to confirm that each indicator can accurately measure its latent variable. An indicator can measure its latent variable if the factor loading coefficient or a discriminant validity value $>$ 0.5 (Ghozali, 2017; Hair et al., 2014).

The data reliability was tested and resulted in the Construct Reliability value using AMOS and the Cronbach's alpha value using SPSS 22. The data is said to be reliable if Cronbach's alpha $>0.6$ and Construct Reliability > 0.7 (Ghozali, 2017). Structural Model Equation can be seen in Figure 2.

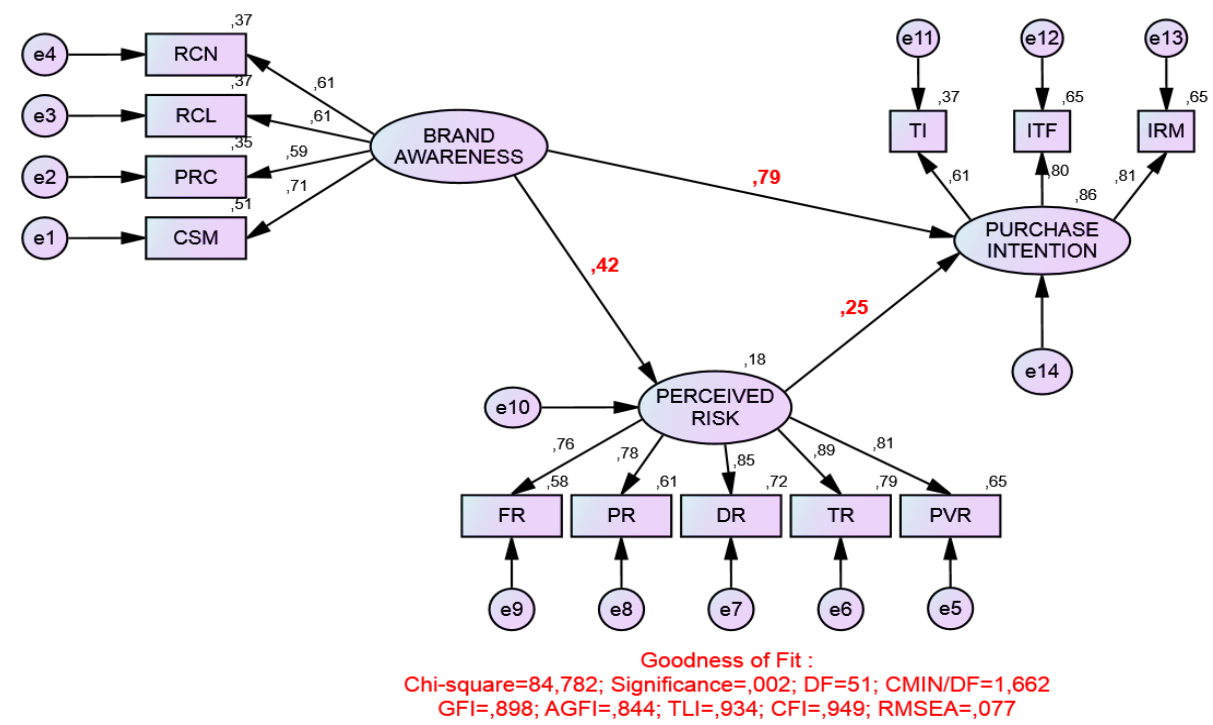

Source: Primary data processed

Figure 2. Structural Equation Modelling

Confirmatory Factor Analysis (CFA) result can be seen in Table 3.

Table 3. Confirmatory Factor Analysis

\begin{tabular}{|c|c|c|c|c|c|c|c|}
\hline \multirow[b]{2}{*}{ Variables } & \multirow[b]{2}{*}{ Items } & \multirow[b]{2}{*}{$\begin{array}{l}\text { Loading } \\
\text { Factor }\end{array}$} & \multirow[b]{2}{*}{$\begin{array}{l}\text { Standard } \\
\text { Error }\end{array}$} & \multirow[b]{2}{*}{$\begin{array}{c}\text { Critical } \\
\text { Ratio }\end{array}$} & \multirow[b]{2}{*}{ P-Value } & \multicolumn{2}{|c|}{ Reliability Tests } \\
\hline & & & & & & $\begin{array}{c}\text { Cronbach's } \\
\text { Alpha }\end{array}$ & $\begin{array}{l}\text { Construct } \\
\text { Reliability }\end{array}$ \\
\hline \multirow[t]{4}{*}{ Brand Awareness } & CSM & 0.712 & \multicolumn{3}{|c|}{ Reference point } & 0.870 & 0.73 \\
\hline & PRC & 0.593 & 0.19 & $5.44^{1}$ & $* * *$ & 0.880 & \\
\hline & RCL & 0.611 & 0.174 & 5.392 & $* * *$ & 0,869 & \\
\hline & $\mathrm{RCN}$ & 0.611 & 0.177 & 5.338 & $* * *$ & 0.878 & \\
\hline \multirow[t]{5}{*}{ Perceived Risk } & PVR & 0.808 & \multicolumn{3}{|c|}{ Reference point } & 0.860 & 0.91 \\
\hline & TR & 0.887 & 0.099 & 10.964 & $* * *$ & 0.864 & \\
\hline & DR & 0.85 & 0.118 & 10.203 & $* * *$ & 0.863 & \\
\hline & PR & 0.783 & 0.139 & 9.243 & $* * *$ & 0.870 & \\
\hline & FR & 0.759 & 0.091 & 8.736 & $* * *$ & 0.864 & \\
\hline \multirow[t]{3}{*}{ Purchase Intention } & TI & 0.607 & \multicolumn{3}{|c|}{ Reference point } & 0.873 & 0.83 \\
\hline & ITF & 0.804 & 0.268 & 6.18 & $* * *$ & 0.863 & \\
\hline & IRM & 0.806 & 0.242 & 6.098 & $* * *$ & 0.864 & \\
\hline
\end{tabular}

Source: Primary data processed 
As seen in Figure 2 and Table 3, the factor loading coefficient indicated by the loading factor $(\lambda)$ value of each item was between $0.593-0.887(>0.5)$ with a Critical Ratio value $>2$ and a $P$-Value $>0.05$, indicating each item was valid to measure the latent variable. The Cronbach's alpha value was between $0.863-0.880(>0.6)$, and the Reliability of the constructs was greater than 0.7 indicating the data was reliable.

The second measurement is the model fit testing to determine the model's fitness conceptualized with the results (Ghozali, 2017). The result can be seen from the Goodness of Fit value from the AMOS output in Table 4.

Table 4. Model Fit Testing

\begin{tabular}{cccc}
\hline Model Fit Testing & Cut-Off Value & Result & Remark \\
\hline Chi-Square & $\mathrm{df}=51, \mathrm{X} 2=68.67$ & 84.72 & Marginal \\
Significance & $\geq 0.05$ & 0.020 & Marginal \\
CMIN-DF & $\leq 2$ & 1.662 & Fit \\
GFI & $\geq 0.80$ & 0.898 & Fit \\
AGFI & $\geq 0.80$ & 0.844 & Fit \\
TLI & $\geq 0.90$ & 0.934 & Fit \\
CFI & $\geq 0.90$ & 0.949 & Fit \\
RMSEA & $0.03-0.08$ & 0.77 & Fit \\
\hline
\end{tabular}

Source: Primary data processed

Based on Table 4, structurally, the data collected can measure the model fitness. In particular, the value of CMIN-DF $=1.622$; GFI $=0.89$; AGFI; 0.8; TLI $=0.934$; CFI $=0.949$ and RMSEA $=0.77$. Although the Chi-Square and significance values did not meet the cut-off value, overall, the structural model meets the good-fit standard (Ghozali, 2017). output below:

The results of the perceived risk role as a mediating variable are shown by the Sobel test

\begin{tabular}{|c|c|c|c|c|c|}
\hline & Input: & & Test statistic: & Std. Error: & $p$-value: \\
\hline$a$ & 0.421 & Sobel test: & 2.41945534 & 0.04402354 & 0.01554377 \\
\hline$b$ & 0.253 & Aroian test: & 2.3809443 & 0.04473561 & 0.01726832 \\
\hline$s_{a}$ & 0.150 & Goodman test: & 2.45989767 & 0.04329977 & 0.01389766 \\
\hline & 0.053 & Reset all & \multicolumn{3}{|c|}{ Calculate } \\
\hline
\end{tabular}

Source: Primary data processed

Figure 3. Sobel Test

Table 5. Hypothesis Results

\begin{tabular}{lccc}
\hline \multicolumn{1}{c}{ Hypothesis } & loading & P & Result \\
factor & Value & Supported \\
Perceived Risk $\leftarrow$ Brand Awareness (H1) & 0.421 & $* * *$ & Supported \\
Purchase Intention $\leftarrow$ Brand Awareness (H2) & 0.793 & $* * *$ & Supported \\
Purchase Intention $\leftarrow$ Perceived Risk (H3) & 0.253 & 0.009 & Supported \\
Perceived Risk $\leftarrow$ Financial Risk (H3a) & 0.759 & $* * *$ & Supported \\
Perceived Risk $\leftarrow$ Product Risk (H3b) & 0.783 & $* * *$ & Supported \\
Perceived Risk $\leftarrow$ Delivery Risk (H3c) & 0.85 & $* * *$ & Supported \\
Perceived Risk $\leftarrow$ Time Risk (H3d) & 0.887 & $* * *$ & Supported \\
Perceived Risk $\leftarrow$ Privacy Risk (H3e) & 0.808 & $* * *$ & Supported (Sobel \\
Purchase Intention $\leftarrow$ Perceived Risk $\leftarrow$ Brand Awareness & 0.107 & 0.01 & Test Statistic $=2.41)$ \\
(H4) & & &
\end{tabular}

$* * *=<0.001$

Source: Primary data processed

The Sobel test results showed that the z-calculated value of 2.41 had a p-value of 0.01 . With a zcalculated value $>1.645$ (sig: 0.05), perceived risk was significantly able to mediate the influence of brand awareness on perceived risk. The hypothesis testing results can be seen in Table 5 . 
Based on data testing with AMOS and Sobel test, there was a positive and significant influence of the relationship among the variables directly or indirectly. Thus, all the hypotheses were accepted.

The result showed that brand awareness positively influenced perceived risk $(\beta=0.421$; $P$-Value less than 0.001). Consumption was the primary indicator measuring brand awareness $(\lambda$ $=0.712 ; P$-Value $<0.001)$, followed by recall and recognition as the central part of brand awareness with the same factor loading value $(\lambda=0.611 ; P$-Value $<0.001)$. Purchase was the smallest factor loading value in measuring brand awareness $(\lambda=0.593$; $P$-value $<0.00)$.

These results indicated that consumers tend to remember Shopee when using other ecommerce applications. When transacting using other e-commerce applications, consumers will compare to Shopee. If it is better than Shopee, consumers can switch to other e-commerce applications in their next shopping. Based on the results, this research confirms that the higher the consumer awareness of a brand, the higher the perception of risks that arise in that brand.

These results also indicated that the higher the brand awareness, the more information about the brand will be obtained. This information will then form the perception. Several recent research defined the perceived risk with various definitions from different points of view by putting forward two essential points: uncertainty and consequences. However, these results did not support other studies stating that brand awareness had a negative effect on perceived risk. Thus, based on the results, the higher the brand awareness, the higher the perceived risk. However, we also want to emphasize that, as uncertainty, the risk perception may change when consumers have consumed the brand.

Based on the results, brand awareness had a positive and significant influence on the purchase intention of Shopee users directly $(\beta=0.793 ; P$-Value $<0.001)$. This variable relationship factor loading value was the highest of the relationship among the variables conceptualized in this research. Thus, the higher the brand awareness, the higher the purchase intention.

These results also confirmed previous studies stating that consumers tend to choose popular brands (Chi, 2009). Based on the results, Shopee is the most recommended e-commerce to make online purchases. IRM indicated the highest value $(\lambda=0.806 ; P$-Value $<0.001)$ in measuring purchase intention. Shopee can be said to have succeeded in performing the branding stage even though it is newer than other well-known e-commerces in Indonesia. The branding process has put Shopee in the minds of consumers through their familiar jingles, orange color identical logo, and the "free shipping" tagline. Free shipping is very effective for consumers considering that Indonesia is an archipelago where shipping goods from one place to another requires much cost.

Through this research, the researchers agree that creating brand awareness is one of the essential tasks of a marketer. More broadly, the brand owner must always pay special attention to the product branding process. Even though it takes a long time, successful product branding will have a good long-term impact on business, especially online business.

Based on the results, perceived risk had a positive and significant influence on the purchase intention of e-commerce consumers. Although the influence was lower $(\beta=0.253$; $P$ Value $=0.009)$, these results confirmed that increased perceived risk would also increase purchase intention.

E-commerce consumers understand all the possible risks in online shopping. Peter \& Ryan (1976) stated that the consumer determines whether or not a brand will be accepted based on the negative risks in buying the brand at the brand level. Based on the results, Shopee users had a high level of perceived risk. However, this did not reduce purchase intention at Shopee.

The results of this research were in line with data from Hootsuite (2020), which showed an increase in the number of online buyers and Shopee as e-commerce with the highest number of visitors in 2020 (iPrice, 2020). The researchers argued that Shopee is currently also very aware of these negative perceptions. Thus, in addition to selling products, Shopee pays necessary attention by providing guarantees to consumers. Therefore, all the conveniences and guarantees from Shopee encourage consumers to keep making purchases. 
Based on the results, privacy risk, time risk, delivery risk, product risk, and financial risk were related and could measure the perceived risk of e-commerce consumers with each factor loading coefficient $>0.5$ and $\mathrm{p}$-value $<0.05$. Thus, H3a, H3b, H3c, H3d, and H3e were accepted. These five dimensions had measured the consequences and negative things in purchasing. Time risk had the highest estimate value $(\lambda=0.887 ; P$-Value $<0.001)$ compared to other risk dimensions. This result showed the time risk was the biggest contribution to the perceived risk in shopping at Shopee. Delivery risk had the second-largest contribution value with $\lambda=0.85 ; P$-Value $<0.001$.

Time risk and delivery risk were at the stage after purchasing. Shopee itself anticipated delivery delays by giving sellers a time limit to deliver the purchased items. If the items can not be delivered simultaneously, the consumer or the system will automatically cancel the order. It is an appropriate form of anticipation in suppressing the perceived risk in the minds of consumers.

Privacy risk was the next indicator measuring perceived risk well $(\lambda=0.808, P$-Value $<$ 0.001). There was no doubt that misuse of personal data was the biggest threat from an online transaction. Likewise, with Shopee users in Makassar City, they doubt if their data (address, debit/credit card number) were kept confidential.

Based on the indirect relationship of brand awareness to purchase intention mediated by perceived risk, the loading factor of indirect effect value was 0.17 . This value was lower than the direct effect of brand awareness on purchase intention.

The Sobel test in Figure 2 showed that perceived risk was significantly able to mediate the influence of brand awareness on purchase intention with the Sobel test value of 2.41 (Greater than 1.645; $P$-Value < 0.01). Thus, perceived risk partially mediated the relationship between brand awareness and purchase intention (Baron \& Kenny, 1986). Although with a relatively small effect compared to the direct relationship between brand awareness and purchase intention, perceived risk was confirmed as an essential thing to consumer behavior in consuming a brand.

In line with previous studies (Hashemi \& Hajiheydari, 2012; Mansour et al., 2015; Petahiang et al., 2015), the known brands will still attract buyers even though having high perceived risk. However, consumers prefer to avoid risks in online shopping. A known brand can directly have a more significant influence in increasing purchase intention than a risk-perceived brand.

\section{Theoretical and Managerial Implications}

This research also clearly showed how attitude, subjective norms, and perceived behavioral control were in the Theory of Planned Behavior. This research showed how positive and negative perceptions could be formed and influence purchase intention in simple terms and full of limitations. Brands with complete information can emergence the purchase intention of consumers.

Based on the results, online business actors should pay special attention to the negative perceived risk from online shopping activities. By understanding all the concerns of consumers, online businesses can implement strategies to minimize the perceived risk. In the end, risk can become a "product" if properly processed by marketers. By minimizing risk, products to be sold online will have a special place in the minds of consumers.

Finally, this research was conducted limited to Shopee users with a small sample. Although statistically the sample size had met the requirements, financially, some samples had low income. Thus, for further research, we hope that researchers will use a more significant number of samples and a more measured approach, such as ensuring that the sample financially has better purchasing power. We suspect that with better financial capability, the level of risk perceived by consumers will also change.

\section{Conclusion and Future Direction}

Based on statistical analysis and structural model fit, brand awareness positively and significantly affected risk perception and purchase intention. Likewise, the effect of risk perception on 
purchase intention was also positive and significant. In this research, product risk, financial risk, time risk, delivery risk, and privacy risk confirmed their role in perceived risk. Thus, perceived risk was able to mediate the effect of brand awareness on purchase intention. However, it is considered a risk of decreasing purchase intention, which can be seen from brand awareness. Without risk perception, brand awareness can have a more significant influence on purchase intention. Further research is also important to discuss in more depth the factors that drive customer intention. Not only external factors such as in this research but further research is also expected to use analysis based on internal factors, such as the emergence of intrinsic motivation, which drives interest in buying or consuming products.

\section{References}

Aaker, D. A., \& Biel, A. L. (2013). Brand equity \& advertising: advertising's role in building strong brands. Psychology Press.

Ajzen, I. (1991). The Theory of Planned Behavior, Organizational behavior, and human decision processes. 50(2), 179-211.

Ariff, M. S. M., Sylvester, M., Zakuan, N., Ismail, K., \& Ali, K. M. (2014). Consumer perceived risk, attitude and online shopping behavior; Empirical evidence from Malaysia. IOP Conference Series: Materials Science and Engineering, 58(1), 012007.

Ariffin, Kamalul S., Mohan, T., \& Goh, Y. N. (2018). Influence of consumers' perceived risk on consumers' online purchase intention. Journal of Research in Interactive Marketing, 12(3), 309_ 327.

Ashoer, M., \& Said, S. (2016). The Impact of Perceived Risk on Consumer Purchase Intention in Indonesia; A Social Commerce Study. Icamess, April, 1-14.

Baron, R. M., \& Kenny, D. A. (1986). The moderator-mediator variable distinction in social psychological research: Conceptual, strategic, and statistical considerations. Journal of Personality and Social Psychology, 51(6), 1173.

Bauer, \& Raymond, A. (1960). Consumer Behavior as Risk. American Marketing Association, 389398.

https://books.google.com/books?hl=en\&lr=\&id=HLuo1 sawoAYC\&oi=fnd\&pg=PA13 \&ots $=$ IfiCaV9tTs\&sig=pnR9mta5LPAtf4Bq8zz1jomSWDQ

Bian, Q., \& Forsythe, S. (2012). Purchase intention for luxury brands: A cross cultural comparison. Journal of Business Research, 65(10), 1443-1451.

Byrne, B. M. (2016). Structural Equation Modeling With AMOS. Routledge, New York

Chen, C. S. (2013). Perceived risk, usage frequency of mobile banking services. Managing Service Quality, 23(5), 410-436.

Chen, R., \& He, F. (2003). Examination of brand knowledge, perceived risk and consumers' intention to adopt an online retailer. Total Quality Management and Business Excellence, 14(6), 677-693.

Chen, Y. S., \& Chang, C. H. (2012). Enhance green purchase intentions: The roles of green perceived value, green perceived risk, and, green trust. Management Decision, 50(3), 502520.

Chi, H. K. (2009). The Impact of Brand Awareness on Consumer Purchase Intention: The Mediating Effect of Perceived Quality and Brand Loyalty. The Journal of International Management Studies, 4(1), 135-144.

Courage, S. K. D., Zakari, M., \& Abel, G. P.-K. (2019). Perceived Online Risk, Consumer Trust, and M-Shopping Behaviour. Journal of Social \& Behavioural Research in Business, 10(1), 10-23.

Dabbous, A., \& Barakat, K. A. (2020). Bridging the online-offline gap: Assessing the impact of 
brands' social network content quality on brand awareness and purchase intention. Journal of Retailing and Consumer Services, 53(November 2018), 101966.

Eggert, A. (2006). Intangibility and Perceived Risk in Online Environments. Journal of Marketing Management, 22(5-6), 553-572.

Fishbein, M., \& Ajzen, I. (1975). Belief, Attitude, Intention and Behavior: An Introduction to Theory and Research. Philosophy and Rhetoric, 10(2), 177-188.

Forsythe, S. M., \& Shi, B. (2003). Consumer patronage and risk perceptions in Internet shopping. Journal of Business Research, 56(11), 867-875.

Ghozali, I. (2017). Model Persamaan Struktural Konsep dan Aplikasi Dengan Program AMOS 24 Update Bayesian SEM (7th ed.). Badan Penerbit Universitas Diponegoro.

Gracia, A., \& De Magistris, T. (2007). Organic food product purchase behavior: A pilot study for urban consumers in the South of Italy. Spanish Journal of Agricultural Research, 5(4), 439451.

Hair, J. F., Patel, M. L., \& K., D. S. G. V. (2014). Amos Covariance-Based Structural Equation Modeling (CB-SEM): Guidelines On Its Application as a Marketing Research Tool. Brazilian Journal of Marketing -BJM Revista Brasileira de Marketing - ReMark Edição Especial.

Hair, J. F., Patel, M. L., K., D. S. G. V., Gabriel, M. L. D. da S., Patel, V. K., Patel, M. L., \& K., D. S. G. V. (2014). Amos Covariance-Based Structural Equation Modeling (CB-SEM): Guidelines On Its Application as a Marketing Research Tool. Brazilian Journal of Marketing -BJM Revista Brasileira de Marketing - ReMark Edição Especial, 13(2), 44-55.

Hashemi, N., \& Hajiheydari, N. (2012). How brand awareness affects online purchase intention: Considering the role of perceived risk. International Journal of Electronic Customer Relationship Management, 6(3-4), 274-291.

Hootsuite. (2020). Hootsuite (We are Social): Indonesian Digital Report 2020. https://andi.link/hootsuite-we-are-social-indonesian-digital-report-2020/

Ilyas, G. B., Rahmi, S., Tamsah, H., \& Munir, A. R. (2020). Reflective Model of Brand Awareness on Repurchase Intention, and Customer Satisfaction. 7(9), 427-438.

Ilyas, G. B., Rahmi, S., Tamsah, H., Munir, A. R., \& Putra, A. H. P. K. (2020). Reflective model of brand awareness on repurchase intention and customer satisfaction. Journal of Asian Finance, Economics and Business, 7(9), 427-438.

Indahingwati, A., Launtu, A., Tamsah, H., Firman, A., Putra, A. H. P. K., \& Aswari, A. (2019). How digital technology-driven millennial consumer behavior in Indonesia. Journal of Distribution Science, 17(8), 25-34.

Indiani, N. L. P., \& Fahik, G. A. (2020). Conversion of online purchase intention into actual purchase: The moderating role of transaction security and convenience. Business: Theory and Practice, 21(1), 18-29.

iPrice. (2020). Peta E-Commerce Indonesia. https://iprice.co.id/insights/mapofecommerce/

Jalilvand, M. R., \& Samiei, N. (2012). The effect of electronic word of mouth on brand image and purchase intention: An empirical study in the automobile industry in Iran. Marketing Intelligence and Planning, 30(4), 460-476.

Jayadi, M. F., \& Ariyanti, M. (2019). The Effect of Perceived Quality, Perceived Risk, Perceived V alue, On Bag Purchase Intention In Visval. 3(07), 41-54.

Jean, B. (2015). Pengaruh Elemen Brand Knowledge dan Brand Equity Terhadap Repurchase Intention. Jurnal Manajemen Program Studi Magister Manajemen Universitas Katolik. Parahiyangan, 14(2), 197-222. 
Khurram, M., Qadeer, F., \& Sheeraz, M. (2018). The Role of Brand Recall, Brand Recognition and Price Consciousness in Understanding Actual Purchase. Journal of Research in Social Sciences, 6(2), 219-241.

Kurniawan, H. A., \& Indriani, F. (2018). Pengaruh Product Knowledge, Perceived Quality, Perceived Risk, dan Perceived Value terhadap Purchase Intention pada Motor Kawasaki Ninja 250 Fi di Kota Semarang. Diponegoro Journal Of Management, 7(4), 1-13.

Lăzăroiu, G., Neguriță, O., \& Grecu, I. (2020). Consumers’ Decision-Making Process on Social Commerce Platforms: Online Trust, Perceived Risk, and Purchase Intentions. Frontiers in Psychology, 11(May), 1-7.

Mansour, K. Ben, Kooli, K., \& Utama, R. (2015). Online Trust Antecedents and Their Consequences on Purchase Intention: An Integrative Approach. Journal of Customer Behavior, 13(1), 25-42.

Marriott, H. R., \& Williams, M. D. (2018). Exploring consumers perceived risk and trust for mobile shopping: A theoretical framework and empirical study. Journal of Retailing and Consumer Services, 42(December 2017), 133-146.

Mitchell, V. (1999). Consumer perceived risk: conceptualizations and models. European Journal of Marketing, 33(1/2), 163-195.

Moisescu, O. I. (2009). the Importance of Brand Awareness in Consumers' Buying Decision and Perceived Risk Assessment. Management \& Marketing, 7(1), 103-110.

Novansa, H., \& Ali, H. (2017). Purchase Decision Model: Analysis of Brand Image, Brand Awareness, and Price (Case Study SMECO Indonesia SME products). Saudi Journal of Humanities and Social Sciences, 2(8), 621-632.

Petahiang, I. L., Mekel, P., \& Worang, F. G. (2015). The Influence of Brand Awareness and Perceived Risk Toward Consumer Purchase Intention on Online Store ( Case Study of the Customer At Feb Unsrat Manado ). Jurnal Berkala Ilmiah Efisiensi, 15(04), 481-492..

Peter, J. P., \& Ryan, M. J. (1976). An Investigation of Perceived Risk at the Brand Level. Journal of Marketing Research, 13(2), 184-188.

Pomalaa, L., Mursityo, Y. T., \& Herlambang, A. D. (2018). Analisis Faktor Brand Awareness , Brand Exposure, Customer Engagement, Dan Electronic Word-of-Mouth Dalam Pemasaran Melalui Media Sosial Pada The Body Shop Indonesia. Jurnal Pengembangan Teknologi Informasi Dan Ilmu Komputer (J-PTIIK) Universitas Brawijaya, 2(10), 4082-4091.

Rubio, N., Oubiña, J., \& Villaseñor, N. (2014). Brand awareness-Brand quality inference and consumer's risk perception in-store brands of food products. Food Quality and Preference, 32(PC), 289-298.

Shahid, Z., Hussain, T., \& Zafar, F. (2017). The Impact of Brand Awareness on the Consumers' Purchase Intention. Journal of Accounting \& Marketing, 06(01), 34-38.

Sharma, J., \& Kurien, D. (2017). Perceived Risk in E-Commerce: A Demographic Perspective. Nmims Management Review, 34(1), 31-57.

Silaban, D., Jaunanda, M., \& Ferdinand, F. (2020). Perceived Risk and Intention to Purchase From Overseas Sellers In Shopee: Jabodetabek Consumer Perspective. 7(2), 259-271.

Sprout. (2019). The Sprout Social Index, Edition XV: Empower \& Elevate. In Sprout Social. https://sproutsocial.com/insights/data/2019-index/

Suleman, D. (2018). Faktor Penentu Keputusan Konsumen Indonesia Memilih Tempat Belanja Disebuah E-Commerce (Theory of Planned Behavior). Jurnal Doktor Manajemen, I(01), 1 9.

Tempo.com. (2020). Survei Markplus: Shopee Paling Diingat Konsumen E-Commerce. 
Tempo.Com. https://bisnis.tempo.com/read/1387374/survei-markplus-shopee-palingdiingat-konsumen-e-commerce $/$ full\&view $={ }_{\mathrm{ok}}$

Tham, K. W., Dastane, O., Johari, Z., \& Ismail, N. B. (2019). Perceived risk factors affecting consumers' online shopping behavior. Journal of Asian Finance, Economics and Business, 6(4), $246-260$.

Ventre, I., \& Kolbe, D. (2020). The Impact of Perceived Usefulness of Online Reviews, Trust and Perceived Risk on Online Purchase Intention in Emerging Markets: A Mexican Perspective. Journal of International Consumer Marketing, 32(4), 287-299.

Wang, E. S. T. (2019). Effects of Brand Awareness and Social Norms on User-Perceived Cyber Privacy Risk. International Journal of Electronic Commerce, 23(2), 272-293.

Wang, X., Yu, C., \& Wei, Y. (2012). Social Media Peer Communication and Impacts on Purchase Intentions: A Consumer Socialization Framework. Journal of Interactive Marketing, 26(4), 198-208.

Wang, Y., \& Hazen, B. T. (2015). Consumer product knowledge and intention to purchase remanufactured products. Intern. Journal of Production Economics, 181, 460-469.

Wu, I. L., Chiu, M. L., \& Chen, K. W. (2020). Defining the determinants of online impulse buying through a shopping process of integrating perceived risk, expectationconfirmation model, and flow theory issues. International Journal of Information Management, 52(May 2019), 102099.

Wu, S. I., \& Ho, L. P. (2014). The influence of perceived innovation and brand awareness on purchase intention of innovation product-An example of iPhone. International Journal of Innovation and Technology Management, 11(4), 1-22.

Yang, C. L., Yi, C. L., \& Wang, Y.-F. (2015). Exploring The Influence Of Tea Beverage Health Claims On Brand Evaluation and Purchase Intention. International Journal of Organizational Innovation, 8(2), 88-99.

Yang, Y., \& Zhang, J. (2009). Discussion on the dimensions of consumers' perceived risk in mobile service. 2009 8th International Conference on Mobile Business, 261-266.

Yunita, D., Nazaruddin, A., \& Nailis, W. (2019). Pengaruh Youtube Advertising terhadap Brand Awareness dan Purchase Intention. Jurnal Manajemen Dan Kewirausahaan, 7(1), 36-46. 